\title{
Invasive species in the flora of the Starobilsk grass-meadow steppe (Ukraine)
}

\author{
Oksana 0. Kucher
}

M.G. Kholodny Institute of Botany of National Academy of Sciences of Ukraine, Tereshchenkivska Str. 2, 01601, Kyiv, Ukraine E-mail address: prykhodko.oksana@mail.ru

\begin{abstract}
The results of an investigation of the invasive species in the flora of the Starobilsk grass-meadow steppe are presented. Check-list of alien plant has over 386 species of vascular plants of which 28 species are invasive. We have identified 6 transformer species from the invasive plants. We aggregate data on the entry, distribution history, ecology, occurrence in different plant communities, degree of their naturalization and the habitats where they occur. The leading families of invasive species are: Asteraceae. The basis for this group is presented by origin from the North America and the Mediterranean. With respect to the time of immigration, most of them are kenophytes. By the method of introduction, ksenophytes are dominated; according to the degree of naturalization epoecophytes and agriophytes dominate in this group. With regard to the characteristics of life forms, half of invasive species are terophytes. The vast majority of plants are heliophytes and xeromesophytes. Most species are found in biotopes group I: Cultivated agricultural biotopes; least of all species found in biotopes group F: Biotopes dominated by chamephytes and nanophanerophytes. Only 3 species found in biotopes group F: Biotopes dominated by chamephytesand nanophanerophytes. The maps of distribution of 28 invasive species are provided. Most of the species marked dispersed in more than 30 squares.
\end{abstract}

KEY WORDS: alien species, plant invasions, Starobilsk grass-meadow steppe, Ukraine

\section{Introduction}

Invasion science focuses on the fate of species introduced through human activities to new geographic areas and the impact of a subset of those alien species that became invasive on resident biota and ecosystems (KUEFFER ET AL., 2013). Many natural ecosystems are unable to effectively resist alien invasions. The areas profoundly transformed by human activities are constantly expanding. Especially important this problem is in the east of Ukraine (PROTOPOPOVA ET AL., 2002). That can be explained by the following facts. First, the natural vegetation of area Starobilsk grass-meadow steppe is highly fragmented, making naturalization of alien species in semi-natural and natural ecosystems easier. Secondly, this happens because of a boundary Starobilsk grass-meadow steppe and human activities (PROTOPOPOVA, 1991).

Invasive species make up $8 \%$ of the alien fraction of the flora and $10 \%$ of invasive species belonging to the "transformers" or "key-stone", alien species can not only apply to the new location, but also change the character, condition, form or nature of ecosystems over large areas (RICHARDSON ET AL., 2000).

The main objectives our research was the selection invasive and transformer species, the study of character the spread in the region, and the impact of their occurrence in plant communities.

\section{Material and methods}

The present research focuses on the invasive species of Starobilsk grass-meadow steppe the alien fraction flora. The investigations are based on original data obtained by routine surveys in 2008-2013, the analysis of data in the literature and examinations of the collections of the Herbaria of M.G. Kholodny Institute of Botany, National Academy of Sciences of Ukraine $(K W)$, Donetsk Botanical Garden, NAS of Ukraine (DNZ), Taras Shevchenko Luhansk National University. KORNAŚ (1968) classification of alien plant species were used (KORNAŚ 1968) and modified by 
PRoTOPOPOVA (1991). Invasive groups determined according RICHARDSON ET AL. (2000). Invasive group is naturalized plants that produce reproductive offspring, often in very large numbers, at considerable distances from parent plants and thus have the potential to spread over a considerable area. Life forms (according to RAUNKIAER, 1934), and morphological types of plants with respect to soil moisture (according to DIDUKH, 2000) of the invasive species were analysed. The species names are given according to MOSYAKIN \& FEDORONCHUK (1999). We aggregate data on the entry, distribution history, ecology, occurrence in the different vegetation communities, degree of naturalization more (PROTOPOPOVA, 1991). We used to analyze habitat classification EUNIS adapted for Ukraine proposal by Ya. Didukh (DIDUKH ET AL., 2011).

The dot map of distribution of invasion species in the region was is based on these herbarium and field data. The squares of UTM system $(100 \times 100 \mathrm{~km})$ were divided into smaller ones $50 \times 50 \mathrm{~km}, 10 \times 10 \mathrm{~km}$ (BUDZHK ET AL., 2009, KUCHER \& GUZ, 2014).

In general, there is a tendency to a permanent increase of the number of alien species in the region flora and increase of the degree of naturalization to some species. "Check-list of flora of South-East of Ukraine" includes 101 alien species; this fraction of flora has increased to 431 species during 25 years (OSTAPKO ET AL., 2010).

\section{Study area}

Starobilsk grass-meadow steppe is located in the east of Ukraine (most part of Luhansk and some districts of Donetsk and Kharkiv regions) with the much anthropogenic changed and transformed plant cover. The regional ecosystems are a heterogenic complex, which includes ravine and artificial forest, meadow-steppe, steppe, river natural vegetation human-made and humanaltered habitats. According to the physical and geographical zoning of Ukraine (MARYNYCH ET. AL., 2003) the situated area belong to the northern subzone, to the steppe zone, to the East European Plain. Square of the study area is near $1900 \mathrm{~km}^{2}$.

Starobilsk grass-meadow steppe has clearly defined boundaries: in the North and in the East the state border with Russian Federation (Rostov and Belgorod region), in the West - the river Oskol (left bank), in the South - the river Seversky Donets (left bank) (Fig. 1).

Except the Seversky Donets, the main rivers are the Aydar, Derkul, Krasna, Evsug, Oskol. The climate of Starobilsk grass-meadow steppe is the most continental in comparison with other the steppe regions of Ukraine. Fertile soils are mainly black soils in the floodplain of the Seversky Donets sandy. On the territory of the region there are large cities Starobilsk, Svatove, Novoaydar, Kupyansk, Sevevodonetsk.

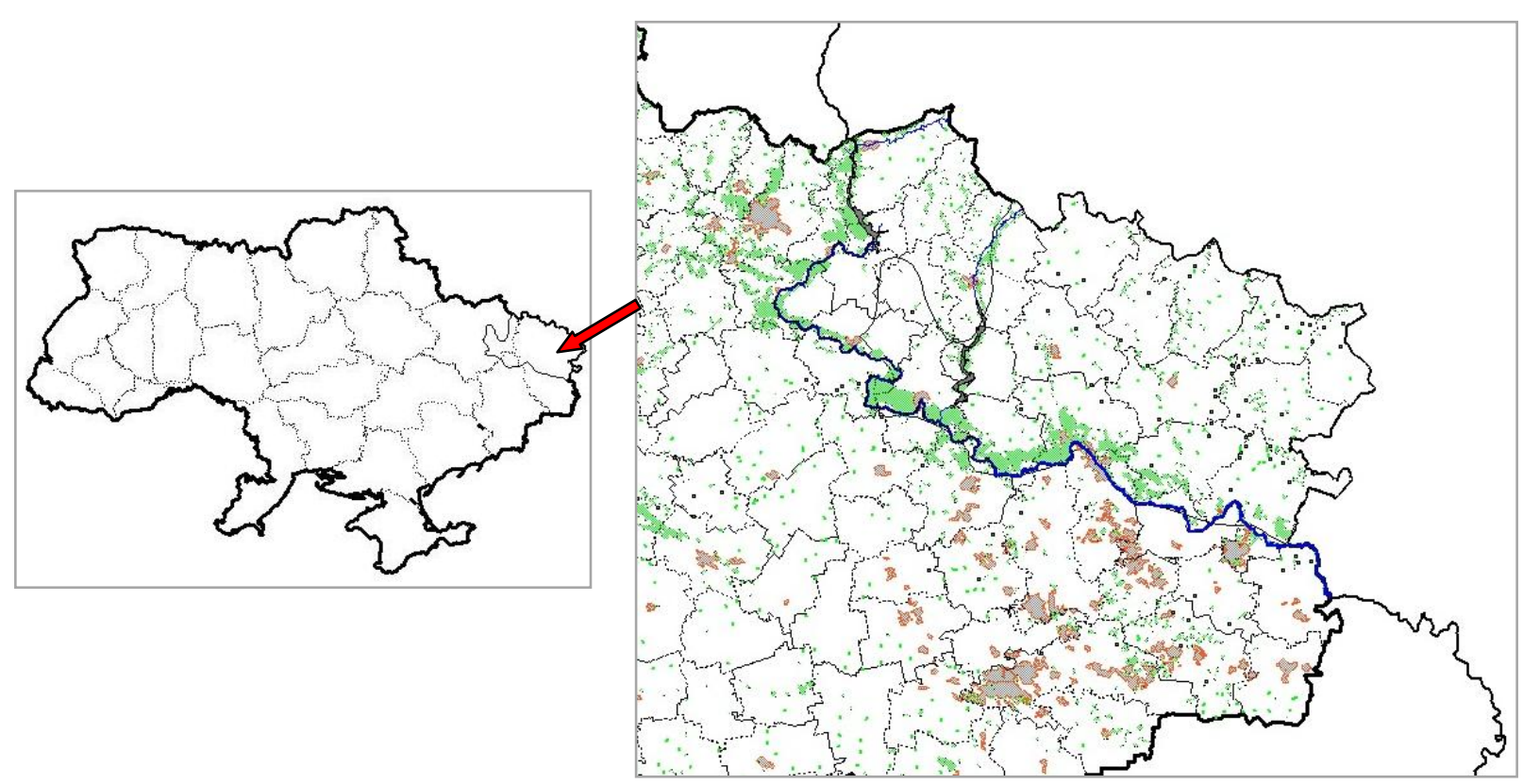

Fig. 1. Location of the Starobilsk grass-meadow steppe

We identified 3 periods of the study of the adventive fraction of Starobilsk grass-meadow steppe (KUCHER, 2011). In the last floristic construction Lugansk region noted for 1838 species
(KoNOPLJA, 2002). In the last publication of the alien flora of the southeast of Ukraine are 431 species, including exclusively for the Lugansk region - 21 (OSTAPKO ET AL., 2010). Most research in the region 
and part alien flora associated with railway lines. Thus, the railways Lugansk region identified 98 species of alien plants (KONOPLJA, 1998). In general, flora Luhansk Nature Reserve for the past 20 years has replenished with 39 alien species (SOVA ET AL., 2000). At the same time, during the 1991-1997 years, more than 30 species almost simultaneously registered in the Lugansk and Donetsk regions (KONOPLJA, 1998; TOKHTAR, 2005).

\section{Results}

Our preliminary check-list of alien faction of flora Starobilsk grass-meadow steppe has over 386 species of vascular plants from 229 genera and 64 families. Most of them are kenophytes (262 sp.), other (104 sp.) are archaeophytes by the time of immigration.

We have noted 28 invasion species: Acer negundo L., Ailanthus altissima (Mill.) Swingle, Amaranthus blitoides S. Watson, Amaranthus retroflexus L., Ambrosia artemisiifolia L., Amorpha fruticosa L., Bidens frondosa L., Bromus squarrosus L., Capsella bursa-pastoris (L.) Medic., Cardaria draba (L.) Desv., Centaurea diffusa Lam., Cichorium intybus L., Conium maculatum L., Coniza canadensis L., Cyclachaena xanthiifolia (Nutt.) Fresen., Diplotaxis tenuifolia (L.) DC., Echinochloa crussgalli (L.) P. Beauv., Elaeagnus angustifolia L., Galinsoga parviflora Cav., Grindelia squarrosa (Pursh) Dunal, Helianthus tuberosus L., Portulaca oleracea L., Robinia pseudoacacia L., Setaria glauca L., Sonchus oleraceus L., Ulmus pumila L., Vicia villosa Roth, Xanthium albinum (Widder.) H. Scholz., which naturalized and actively spread through the region

The leading families of invasive species are: Asteraceae (11 sp.), Fabaceae, Brassicaceae and Poaceae (3 each), Amaranthaceae (2). The invasive species of adventive fraction flora of the Starobilsk grass-meadow steppe are varying in origin. The basis for this group is presented by origin from the North America (13 species), the Mediterranean (7) and Asia (5), the unknown origin (1). With respect to the time of immigration, most of them are kenophytes (20 species); archeophytes - only 8 species. By the method of introduction, ksenophytes are dominated; ergaziophytes are only 7 species. According to the degree of naturalization epoecophytes and agriophytes dominate in this group. With regard to the characteristics of life forms, the largest group consists of annuals (14 sp.), biennials and perennial (8); on last shrubs and trees (6). For species of this group the constant monitoring is carried out. We have identified 6 transformer species from the invasive plants: Acer negundo, Amaranthus retroflexus, Ambrosia artemisiifolia, Amorpha fruticosa, Grindelia squarrosa, Ulmus pumila.

Below there is a brief description of invasive species according to scheme which include the next characteristics: chronological element, origin, degree of naturalization, way of distribution, life form, hydromorphe, heliomorphe.

Acer negundo - kenophytes of North American origin; according to degree of naturalization is agriophytes, according way of distribution is ergasiophytes, according life forms is phanerophytes, according hydromorphe is xeromesophytes, according heliomorphe is scyheliophytes. This species was monodominant in the floodplain in many places of Seversky Donets River and its tributaries. The species inhibits the growth of seedlings, due to its biological properties (Vinogradova, 2009). The species of Acer is distributed mainly on the road and railways. The species is common in all towns in the region of ruderal habitats, where due to the rapid growth inhibits the growth of other species. The species found in biotopes group G: Biotopes dominated by phanerophytes (G1.115) and group I: Cultivated agricultural biotopes (I2.22, I2.31, I3.2, I4.111, I4.12, I4.21, I4.24). Species marked in most squares (Fig. 2).

Ailanthus altissima - kenophytes of Eastern Asia origin, epoecophytes, ergasiophytes, phanerophytes, mesophytes, heliophytes. Species is found in Parham and squares. Often A. altissima grows in settlements near cultivation sites. Species spreads very with fast Species found in biotopes group I: Cultivated agricultural biotopes (I4.111, I4.12, I4.21, I4.24, I5.2). Species marked in a small number of squares -20 pieces (Fig. 3 ).

Amaranthus blitoides - kenophytes of North American origin, epoecophytes, ksenophytes, terophytes, xeromesophytes, heliophytes. Species is found in the ways of communication: road and railways. Found in pastures, gardens and at sites with sandy soil. This species of Amaranthus found in biotopes group E: Mesophitic and xerophitic grasslands with dominance of hemicryptophytes (E3.13), group G: Biotopes dominated by phanerophytes (G2.215) and group I: Cultivated agricultural biotopes (I1.12, I2.13, I2.22, I2.32, I4.21). Species marked dispersed in a small number of squares - 18 pieces (Fig. 4).

Amaranthus retroflexus - kenophytes of North American origin, esepekophytes, ksenophytes, terophytes, mesoxerophytes, heliophytes. It stands moderate shading. This species of Amaranthus often is occurs on disturbed soils along roads. Often A. retroflexus is found in floodplains of Seversky Donets River, on good moist and rich soils. Species found in biotopes group E: Mesophitic 
and xerophitic grasslands with dominance of hemicryptophytes (E3.13 E3.22), group G: Biotopes dominated by phanerophytes (G2.215), and group

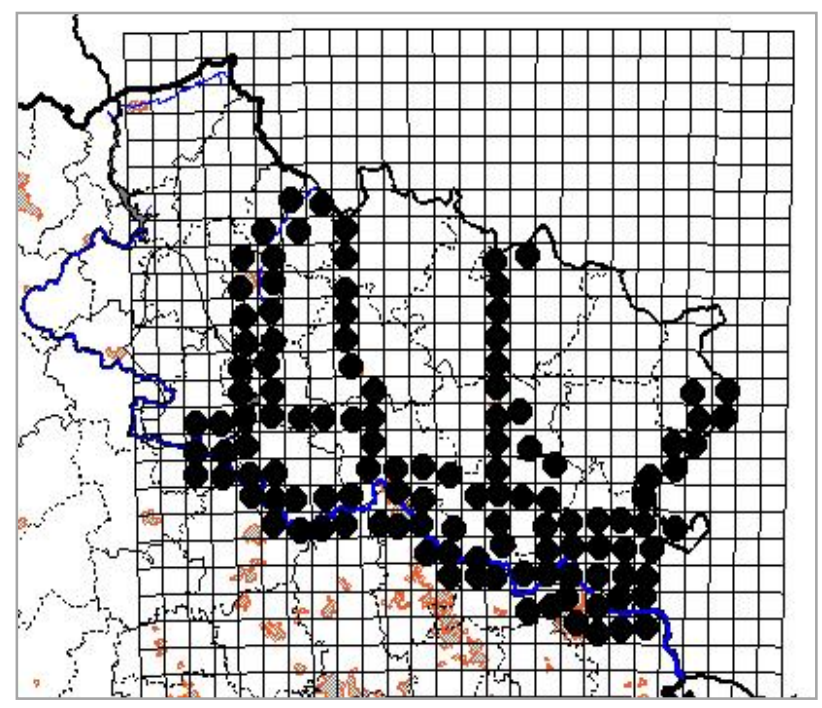

Fig. 2. The map of the distribution of Acer negundo L. in the Starobilsk grass-meadow steppe

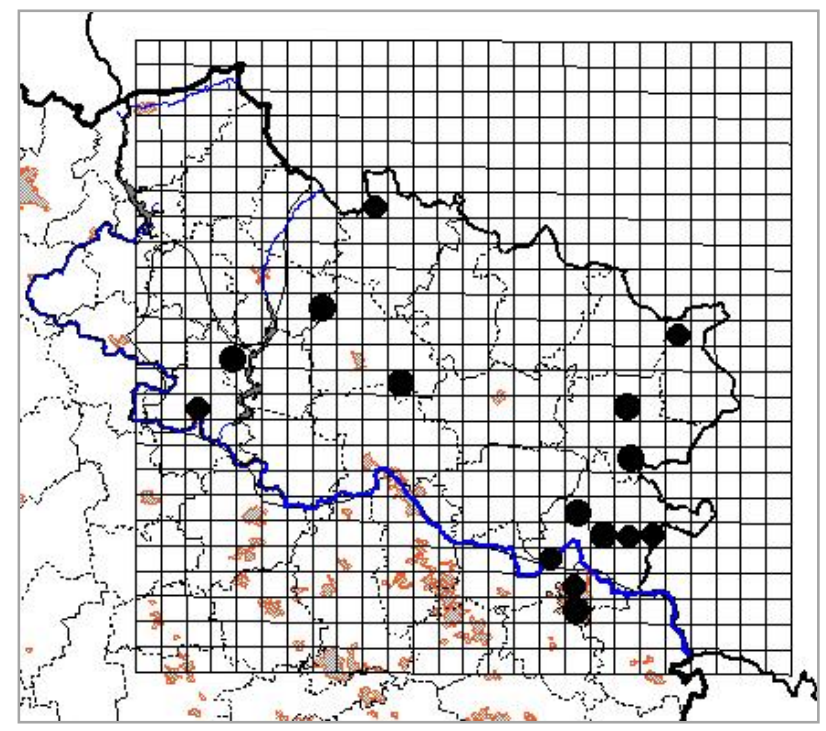

Fig. 4. The map of the distribution of Amaranthus blitoides S. Watson in the Starobilsk grass-meadow steppe

Ambrosia artemisiifolia - kenophytes of North American origin, epoecophytes, ksenophytes, terophytes, xeromesophytes, heliophytes. Consistently, A. artemisiifolia occurs along the road and railways and in almost all towns in ruderal places, at the Starobilsk grass-meadow steppe. Recently, often we found species in the floodplain of the Seversky Donets River and its tributaries (Aydar, Derkul), and on fallow agricultural land in ruderal bushes. Species is distributed on sandy soils but we also found it on humus-rich soils. A. artemisiifolia found in biotopes group D: Water-logged biotopes (D1.221), group E: Mesophitic and xerophitic grasslands with
I: Cultivated agricultural biotopes (I1.12, I2.13, I2.22, I2.241, I2.31, I3.1, I4.111, I.21, I4.24, I5.2). Species marked in most squares (Fig. 5).

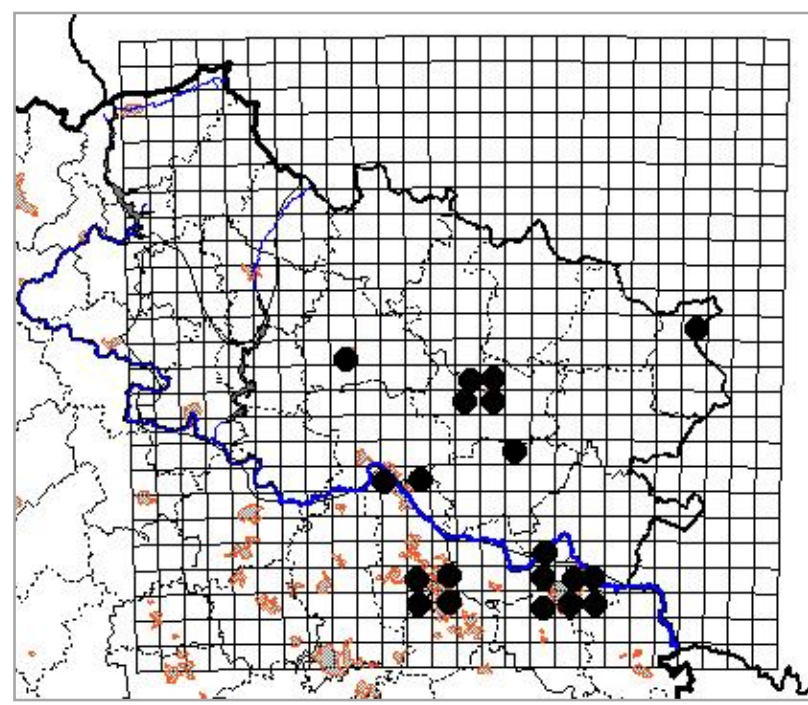

Fig. 3. The map of the distribution of Ailanthus altissima (Mill.) Swingle in the Starobilsk grass-meadow steppe

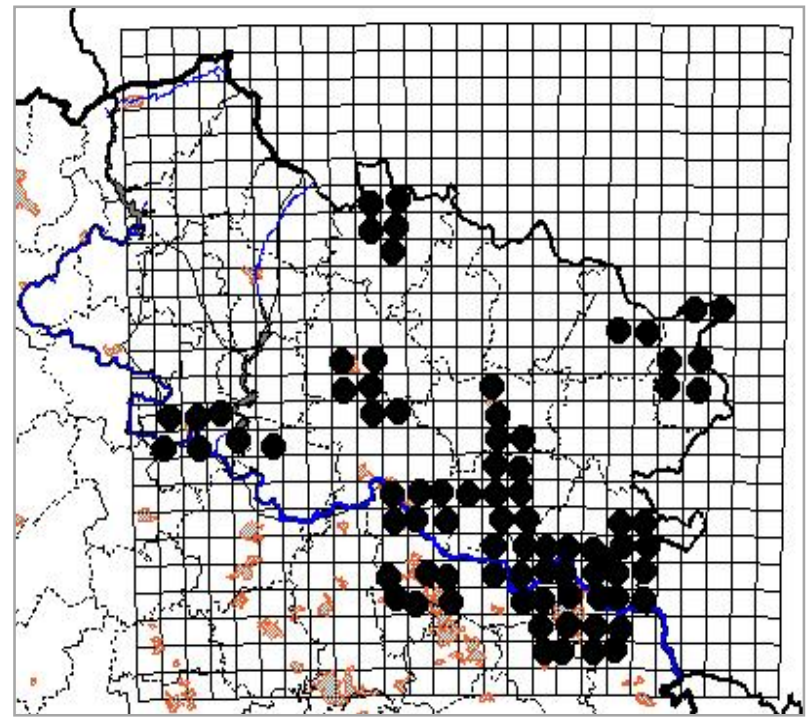

Fig. 5. The map of the distribution of Amaranthus retroflexus $\mathrm{L}$. in the Starobilsk grass-meadow steppe

dominance of hemicryptophytes (E2.122, E2.123), group G: Biotopes dominated by phanerophytes (G2.15), and group I: Cultivated agricultural biotopes (I2.13,I2.22, I2.241,I2.32, I3.1, I4.111,I4.21, I4.24, I5.2). Species marked in most squares (Fig. 6).

Amorpha fruticosa - kenophytes of North American origin, epoecophytes, ergasiophytes, phanerophytes, mesophytes, heliophytes. In Starobelsk grass-meadow steppe there are mainly species confined to artificial pine stands on sandy soils. Now $A$. fruticosa active extends in floodplain the Seversky Donets River and its tributaries. Species found in biotopes group E: Mesophitic and xerophitic grasslands with dominance of 
hemicryptophytes (E3.13), group G: Biotopes dominated by phanerophytes (G1.115,G2.215), and group I: Cultivated agricultural biotopes (I2.31, I3.2, I4.112, I4.12, I4.21, I4.24). Species marked small groups in a minor amount of squares 35 pieces (Fig. 7).

Bidens frondosa - kenophytes of North American origin, epoecophytes, ksenophytes, terophytes, mesophytes, heliophytes. Species occurs in floodplains and along water bodies. As well, $B$. frondosa L. growing in ditches and low wetland areas near the housing. The species found in biotopes group D: Water-logged biotopes (D1.221, D1.32, D1.33), group E: Mesophitic and xerophitic grasslands with dominance of hemicryptophytes (E1.31), and group I: Cultivated agricultural biotopes

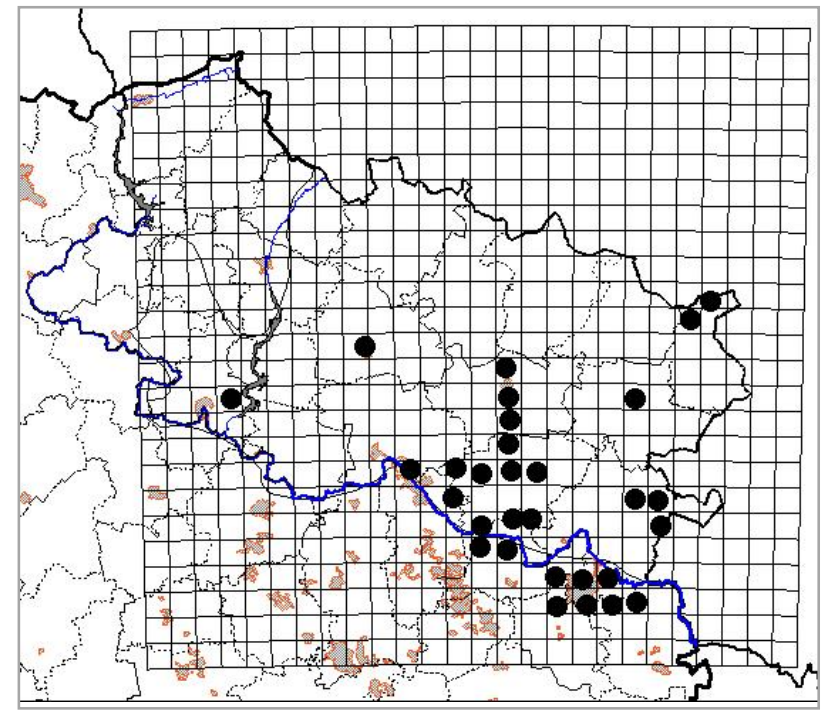

Fig. 6. The map of the distribution of Ambrosia artemisiifolia L. in the Starobilsk grass-meadow steppe

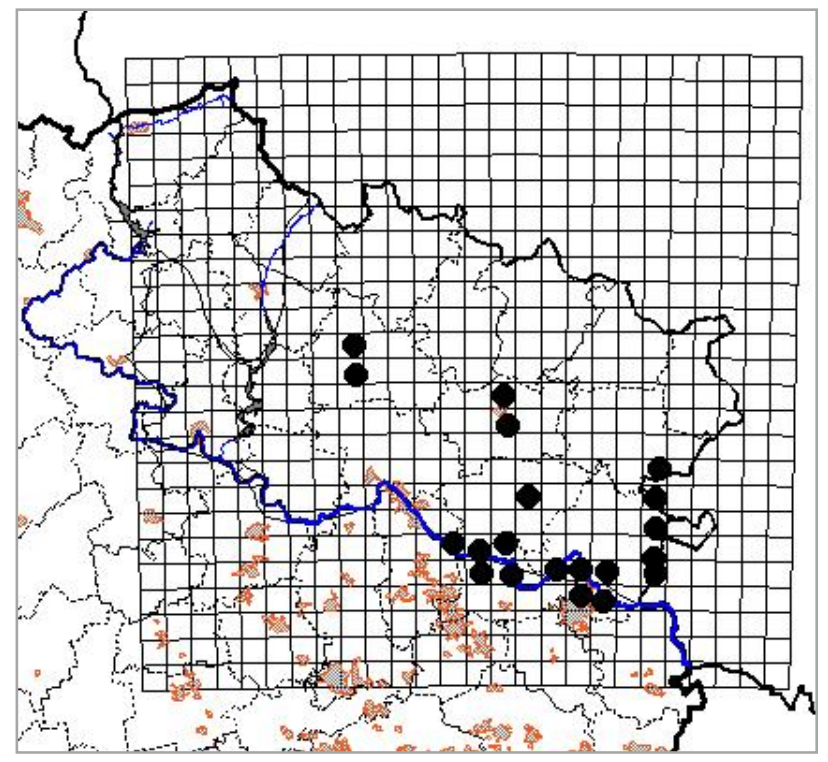

Fig. 8. The map of the distribution of Bidens frondosa $\mathrm{L}$. in the Starobilsk grass-meadow steppe
(I2.22, I2.32, I3.1, I4.21). Species marked small groups in a minor amount of squares (Fig. 8).

Bromus squarrosus - kenophytes of Mediterraneum-Iran-Turanian origin, epoecophytes, ksenophytes, terophytes, xeromesophytes, heliophytes. Species is found in the steppe areas along the road and railways. Often B. squarrosus grows near the housing and on the border fields on those places where regular mowing. Species found in biotopes group E: Mesophitic and xerophitic grasslands with dominance of hemicryptophytes (E3.13), and group I: Cultivated agricultural biotopes (I1.11, I2.13, I2.242, I2.32, I3.1, I4.112, I4.21). Species marked dispersed in a small number of squares - 25 pieces (Fig. 9).

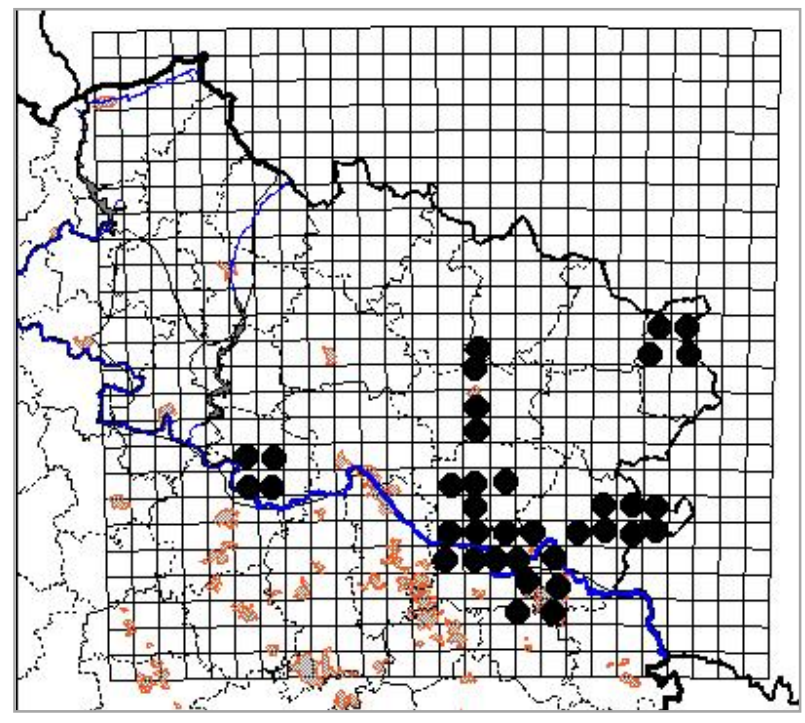

Fig. 7. The map of the distribution of Amorpha fruticosa L. in the Starobilsk grass-meadow steppe

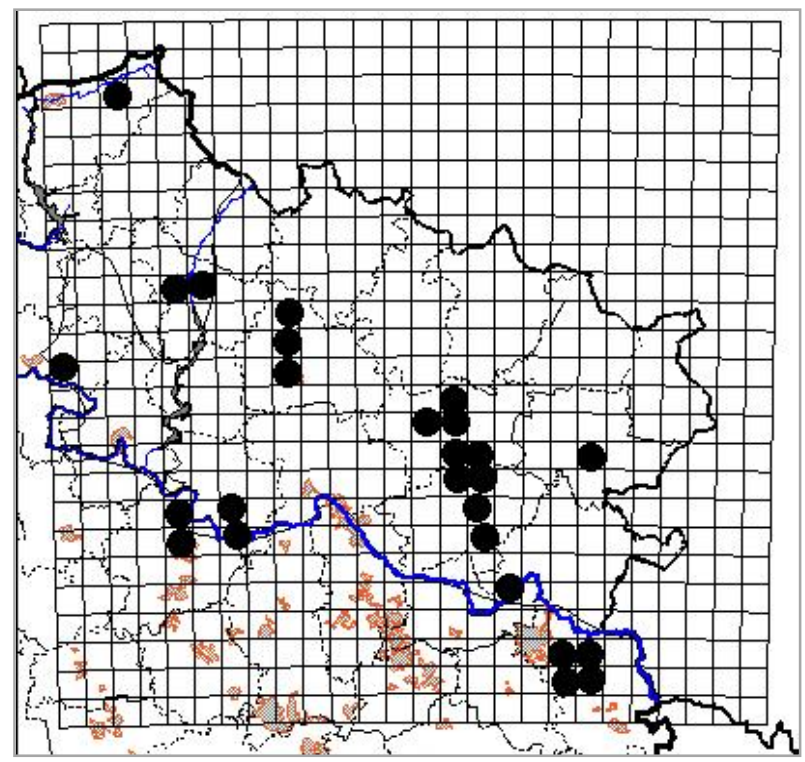

Fig. 9. The map of the distribution of Bromus squarrosus $\mathrm{L}$. in the Starobilsk grass-meadow steppe 
Capsella bursa-pastoris - archaeophytes of unknown origin, epoecophytes, ksenophytes, terophytes, xeromesophytes, heliophytes. The species is widespread in the region. This species of Capsella found on the steppe areas, pastures, on ruderal places near the housing at industrial sites, in the fields as a weed. Species found in biotopes group E: Mesophitic and xerophitic grasslands with dominance of hemicryptophytes (E2.122, E2.123), and group I: Cultivated agricultural biotopes (I1.12, I2.13, I2.242, I2.33, I3.1, I4.111, I4.21, I.4.24, I5.2). Species marked dispersed in a small number of squares (Fig. 10).

Cardaria draba - kenophytes of South European Asian origin, epoecophytes, hemyryptophytes, ksenophytes, xeromesophytes, heliophytes. Species grows in the steppe areas with different types of soils, pastures and roadsides. Also, C. draba found in fields and gardens as a weed. As the city species grows in ruderal places, in flower beds and lawns. Species found in biotopes group E: Mesophitic

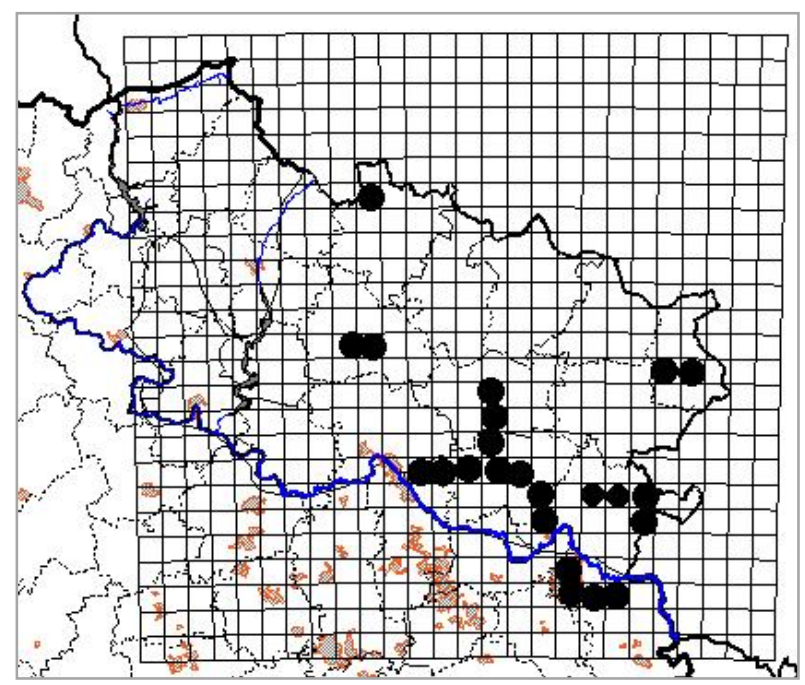

Fig. 10. The map of the distribution of Capsella bursa-pastoris (L.) Medic. in the Starobilsk grass-meadow steppe

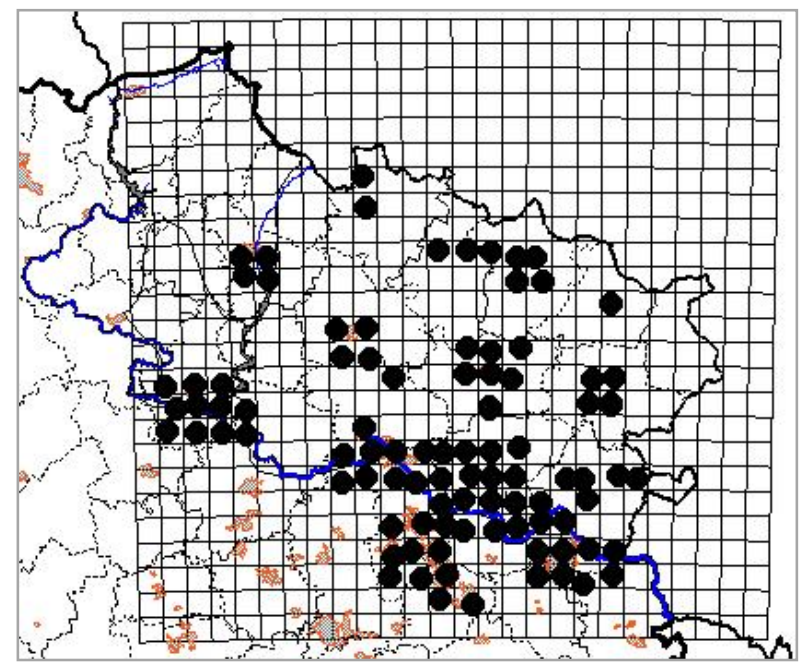

Fig. 12. The map of the distribution of Centaurea diffusa Lam. in the Starobilsk grass-meadow steppe and xerophitic grasslands with dominance of hemicryptophytes (E2.123, E2.231, E2.231), group F: Biotopes dominated by chamephytes and nanophanerophytes (F3.12), and group I: Cultivated agricultural biotopes (I1.12, I2.21, I2.32, I4.24). Species marked small groups in a minor amount of squares (Fig. 11).

Centaurea diffusa - kenophytes of Mediterraneum -Iranian origin, epoecophytes, hemyryptophytes, ksenophytes, mesoxerophytes, heliophytes. Species is found in pastures, rocky steppe areas. Sometimes, C. diffusa grows in in thickets of bushes and ruderal places. Species found in biotopes group E: Mesophitic and xerophitic grasslands with dominance of hemicryptophytes (E2.123 E2.231, E2.231), group F: Biotopes dominated by chamephytes and nanophanerophytes (F3.12), and group I: Cultivated agricultural biotopes (I2.21, I2.241, I3.1, I4.23). Species marked dispersed in a small number of squares (Fig. 12).

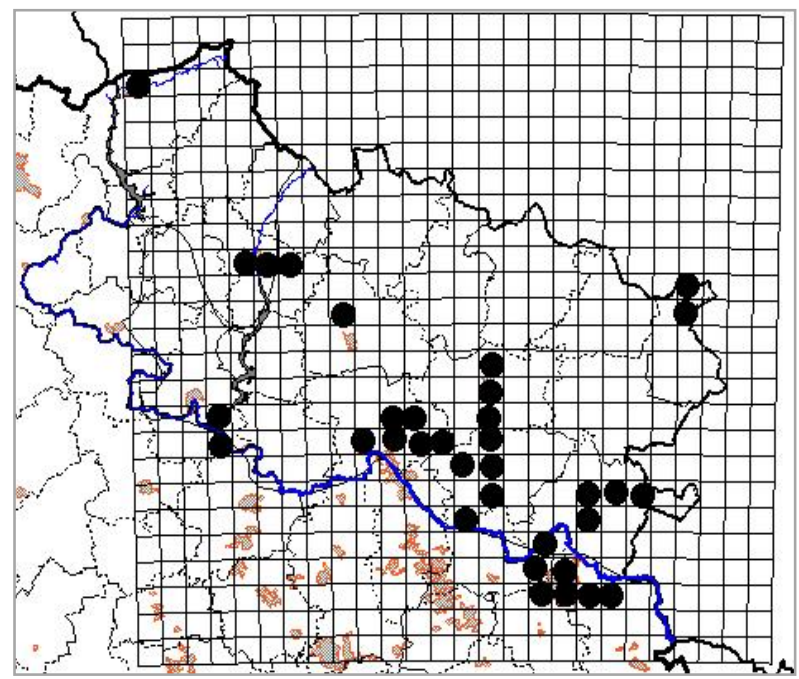

Fig. 11. The map of the distribution of Cardaria draba (L.) Desv. in the Starobilsk grass-meadow steppe

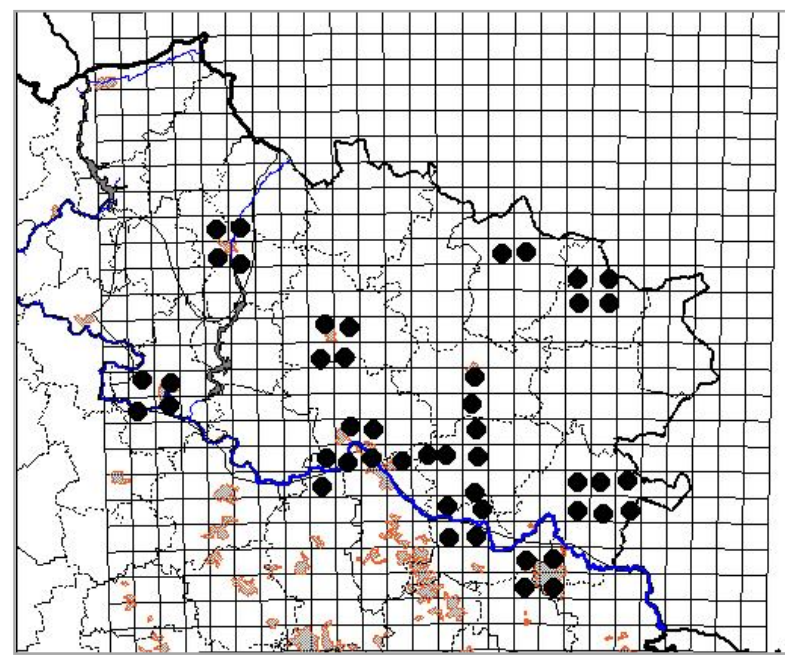

Fig. 13. The map of the distribution Cichorium intybus $\mathrm{L}$. in the Starobilsk grass-meadow steppe 
Cichorium intybus - archaeophytes of Mediterraneum-Iran-Turanian origin, epoecophytes, ksenophytes, hemyryptophytes, xeromesophytes, heliophytes. This species is very common in the steppe areas, along roads in the furrows of the fields. C. intybus grows in ruderal places and participation are regularly mown. Species found in biotopes group E: Mesophitic and xerophitic grasslands with dominance of hemicryptophytes (E2.122, E2.123, E3.13, E3.22), group F: Biotopes dominated by chamephytes and nanophanerophytes (F3.12), and group I: Cultivated agricultural biotopes I1.11, I1.12, I2.21, I2.241, I2.32, I4.111, I4.12, I4.21, I4.23, I4.24). Type most marked squares uniformly throughout the region. Species marked in most squares uniformly throughout the region (Fig. 13).

Conium maculatum - archaeophytes of Mediterraneum-Iran-Turanian origin, epoecophytes, ksenophytes, terophytes, csyheliophytes, mesophytes. Species is found in shelterbelts, in

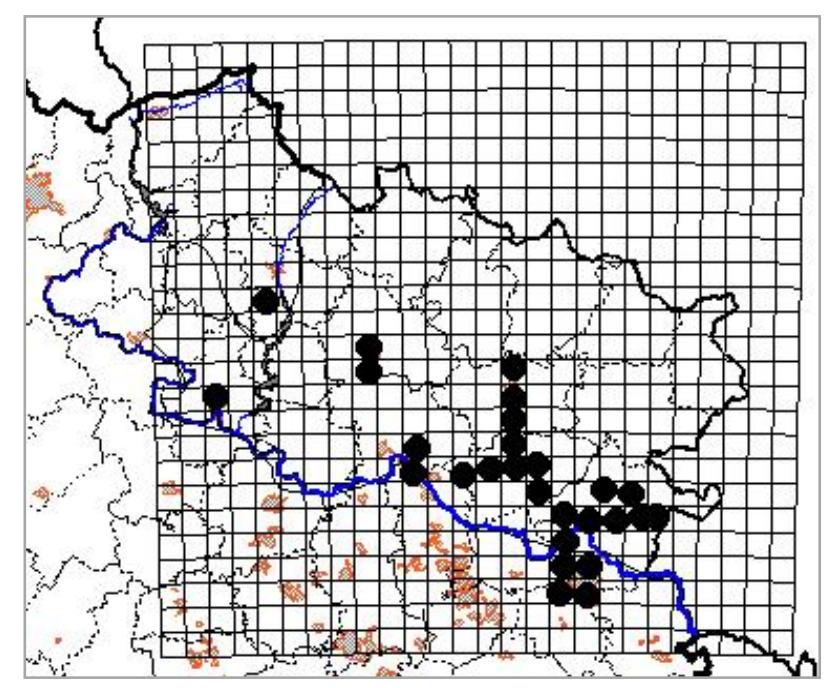

Fig. 14. The map of the distribution of Conium maculatum L. in the Starobilsk grass-meadow steppe

Cyclachaena xanthiifolia - kenophytes of North American origin, epoecophytes, ksenophytes, terophytes, xeromesophytes, heliophytes. Species grows in ruderal areas, along roads and railways. The same C. xanthiifolia occurs in the fields among the crops. Species found in biotopes group D: Water-logged biotopes (D1.221), group E: Mesophitic and xerophitic grasslands with dominance of hemicryptophytes (E3.13, E3.22), and group I: Cultivated agricultural biotopes (I1.12, I2.22, I2.31, I2.32, I3.1, I4.111, I4.112, I4.12, I4.21, I4.24, I5.2). Species marked in most squares uniformly throughout the region (Fig. 16).

Diplotaxis tenuifolia - archaeophytes of Mediterraneum origin, epoecophytes, ksenophytes, terophytes, xeromesophytes, heliophytes. Species grows on industrial sites, along roads and near floodplains, in shady and humid places. Sometimes C. maculatum growing in artificial forest plantations. Species is found only in biotopes group I: Cultivated agricultural biotopes (I2.22, I2.32, I4.111, I4.12, I4.23, I4.21, I4.24). Species marked small groups in a minor amount of squares. (Fig. 14).

Coniza canadensis - kenophytes of North American origin, epoecophytes, ksenophytes, terophytes, mesoxerophytes, heliophytes. Species grows as a weed in fields, often found along the roads. C. canadensis may occur in towns near housing. Often species noted on the railways and industrial sites. C. canadensis found in biotopes group E: Mesophitic and xerophitic grasslands with dominance of hemicryptophytes (E2.122, E2.123, E3.13), group G: Biotopes dominated by phanerophytes (G2.215), and group I: Cultivated agricultural biotopes (I1.11,I2.23, I2.241, I2.31, I2.32, I3.1, I4.111, I4.112, I4.24). Species marked dispersed in a small number of squares (Fig. 15).

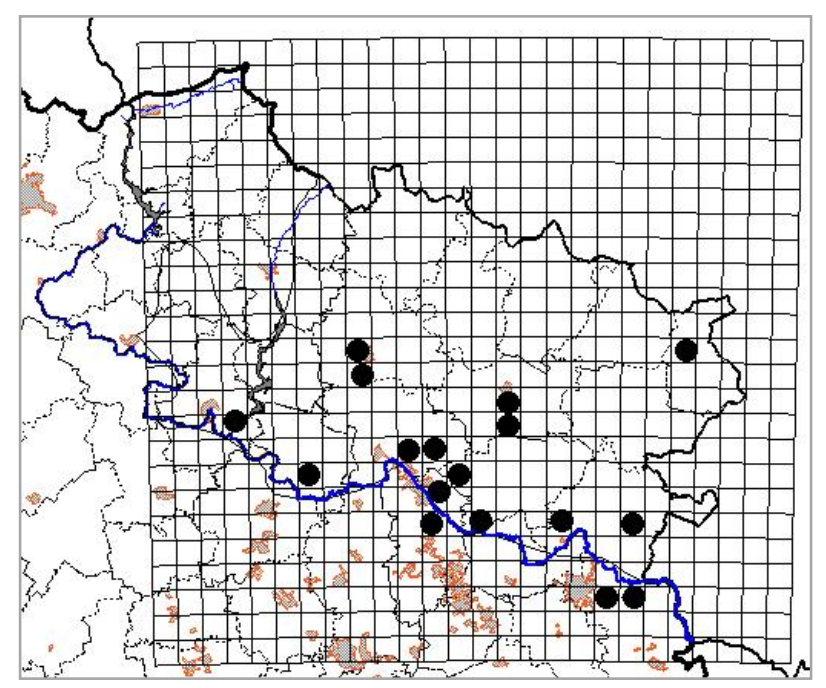

Fig. 15. The map of the distribution of Coniza canadensis L. in the Starobilsk grass-meadow steppe

homes. Sometimes, D.tenuifolia occurs in steppe areas with rocky soil. Species found in biotopes group E: Mesophitic and xerophitic grasslands with dominance of hemicryptophytes (E3.13), and group I: Cultivated agricultural biotopes (I1.12, I2.32, I4.111, I4.21, I5.2). Species marked dispersed in a small number of squares (Fig. 17).

Echinochloa crussgalli - archaeophytes of Asian origin, epoecophytes, ksenophytes, terophytes, mesophytes, heliophytes. Species grows in the nitrogen-rich soils in ruderal places. As a weed, E. crussgalli found in lawns and flower beds in settlements. The species is found only in group I: Cultivated agricultural biotopes (I1.11, I2.22, I2.241, I2.32, I3.1, I4.111, I4.21, I5.2). Species marked small groups in a minor amount of squares (Fig. 18). 
Elaeagnus angustifolia - kenophytes of Mediterraneum origin, agriophytes, ergasiophytes, phanerophytes, mesoxerophytes, heliophytes. Species occurs in settlements near the housing and parks. This species of Elaeagnus growing along the roads where spreads rapidly self-seeding on the steppe areas. Sometimes, E. angustifolia

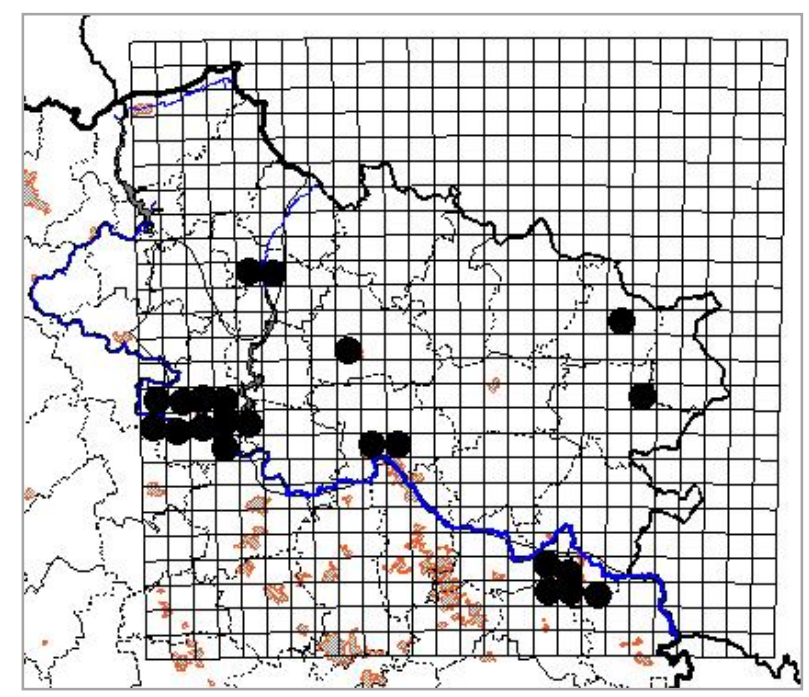

Fig. 16. The map of the distribution of Cyclachaena xanthiifolia (Nutt.) Fresen. in the Starobilsk grass-meadow steppe

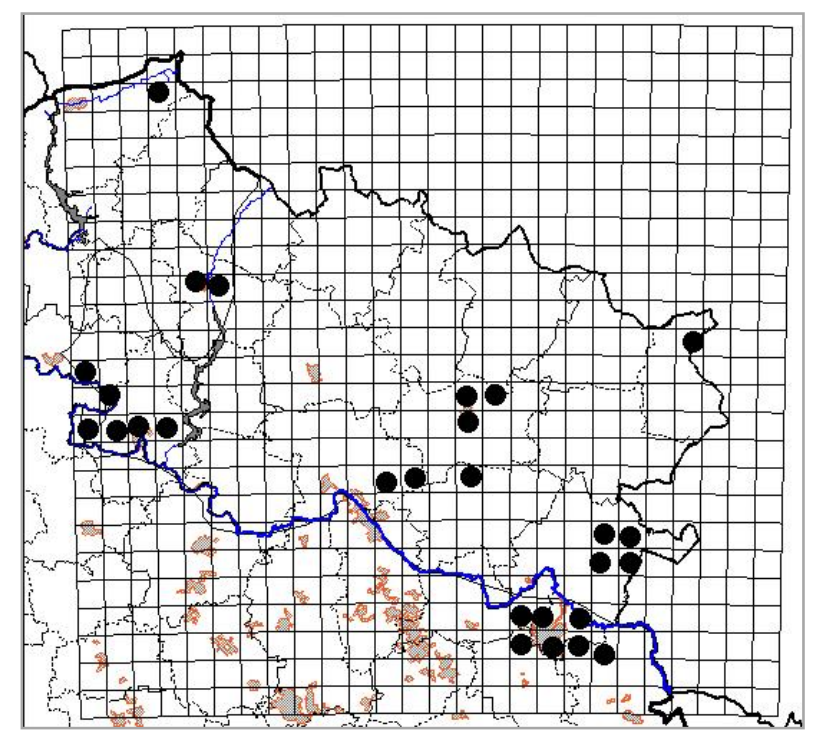

Fig. 18. The map of the distribution of Echinochloa crussgalli

(L.) P. Beauv. in the Starobilsk grass-meadow steppe

Galinsoga parviflora - kenophytes of American origin, epoecophytes, ksenophytes, terophytes, mesoxerophytes, heliophytes. Species grows on moist shady places, in gardens, in the ditches. As often, G. parviflora found in cities flower beds and lawns. The species is found only in group I: Cultivated agricultural biotopes (I1.12, I2.22, I2.31, I4.111, I4.21, I5.2). Species marked dispersed in a small number of squares (Fig. 20). found in floodplains and at the foot of the cretaceous-debugged. Species found in biotopes group G: Biotopes dominated by phanerophytes (G1.115), and group I: Cultivated agricultural biotopes (I2.32, I3.2, I4.111, I4.12, I4.21). Species marked small groups in a minor amount of squares (Fig. 19).

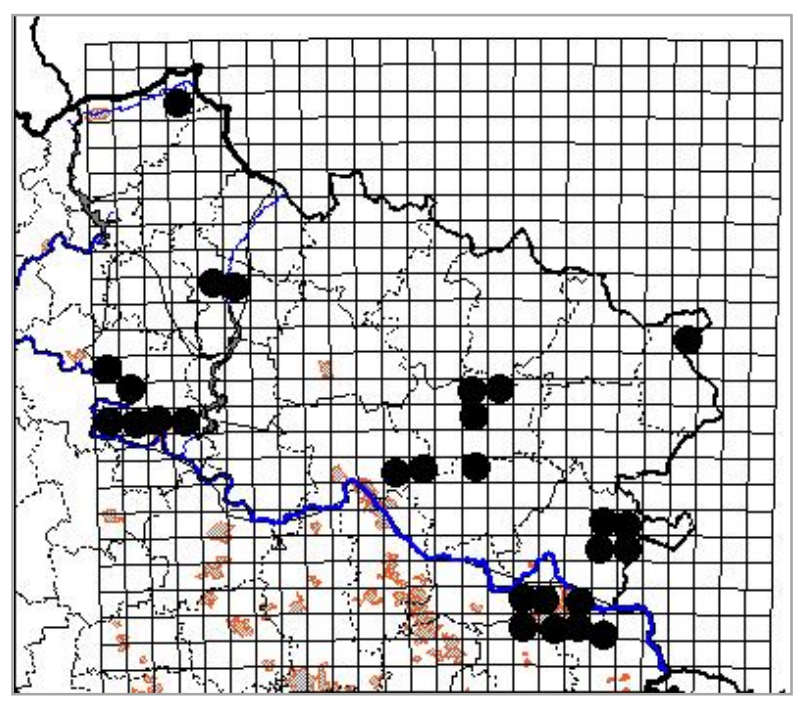

Fig. 17. The map of the distribution of Diplotaxis tenuifolia (L.) DC. in the Starobilsk grass-meadow steppe

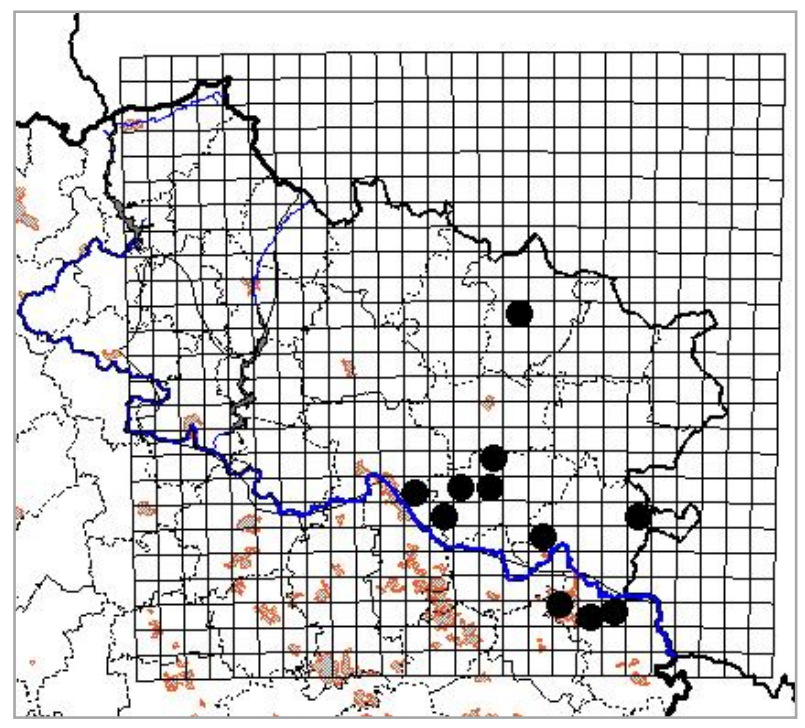

Fig. 19. The map of the distribution of Elaeagnus angustifolia L. in the Starobilsk grass-meadow steppe

Grindelia squarrosa - kenophytes of North American origin, epoecophytes, ksenophytes, hemyryptophytes, xeromesophytes, heliophytes (PROTOPOPOVA ET AL., 2002). Species is found mainly along the roads, even on disturbed soils and floodplains. This species of Grindelia marked on the steppe areas where grazing has been active, sometimes found in cities on the lawns. Species found in biotopes group E: Mesophitic and xerophitic grasslands with dominance of hemicryptophytes 
(E2.123, E3.13), and group I: Cultivated agricultural biotopes (I2.13, I2.23, I2.241, I2.32, I3.1,I4.111, I4.21, I4.24, I5.1). Greatest density was noted in the primary focus the species distribution, in addition the species was marked in squares outside the primary focus (Fig. 21).

Helianthus tuberosus - kenophytes of North American origin, ergasiophygophytes, ergasiophytes, hemyryptophytes, mesophytes, heliophytes. Species is found on roadsides, in fields. Often, $H$. tuberosus marked on ruderal places and near housing. Also, we found of species near elevator and oil reprocessing plants. Species found in biotopes group E: Mesophitic and xerophitic grasslands with dominance of hemicryptophytes (E3.13), and group I: Cultivated agricultural biotopes (I1.12,

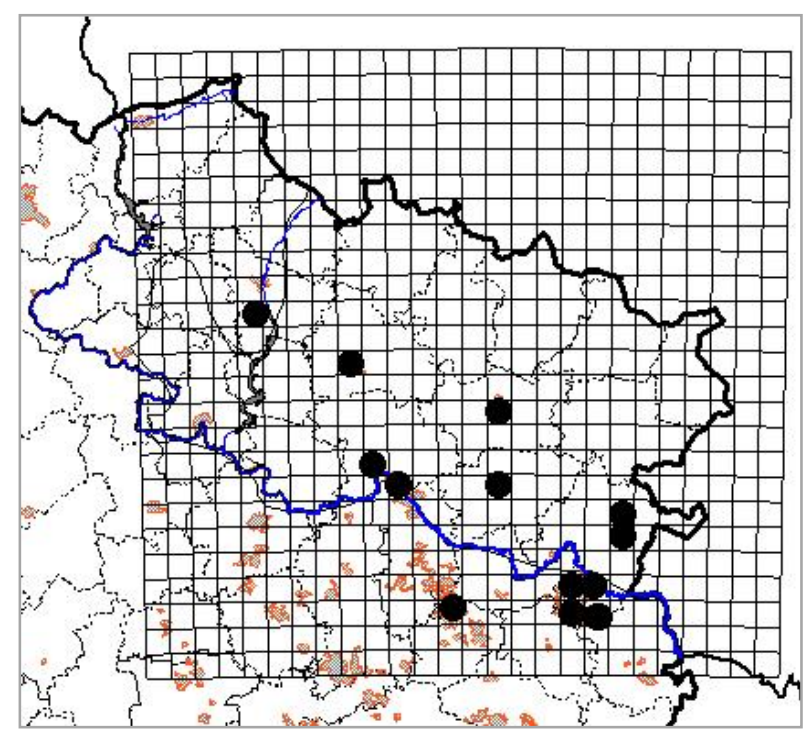

Fig. 20. The map of the distribution of Galinsoga parviflora Cav. in the Starobilsk grass-meadow steppe

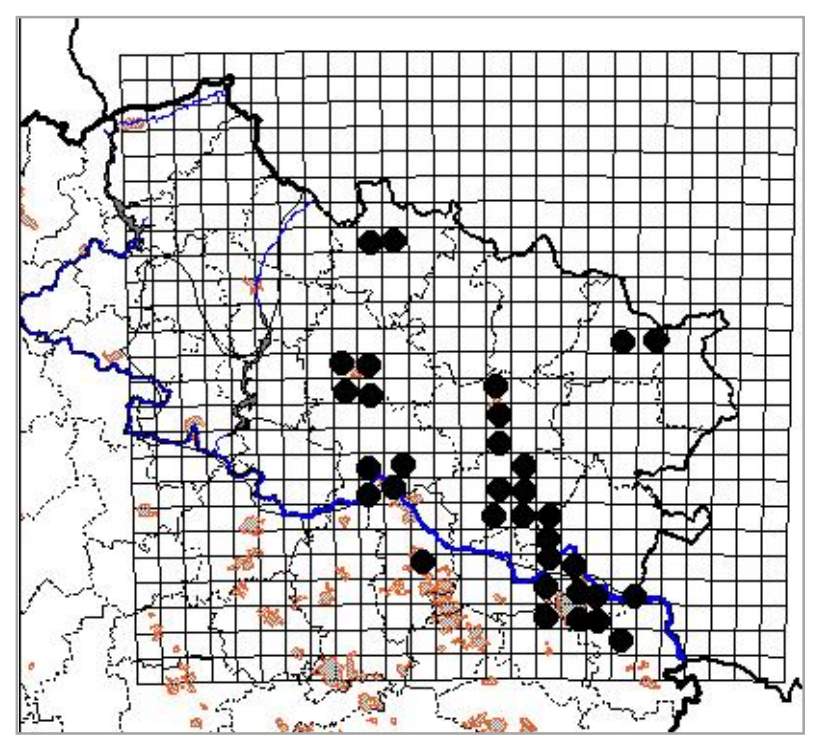

Fig. 22. The map of the distribution of Helianthus tuberosus L. in the Starobilsk grass-meadow steppe
I2.21, I2.22, I2.242, I2.13, I2.32, I4.112, I4.21). Species marked dispersed in a small number of squares (Fig. 22).

Portulaca oleracea - archaeophytes of IranTuranian origin, epoecophytes, ergasiophytes, terophytes, xeromesophytes, heliophytes. Species grows as a weed in fields and gardens in the light areas with sandy soil. As often, P. oleracea found along roads and pine forests. Species found in biotopes group E: Mesophitic and xerophitic grasslands with dominance of hemicryptophytes (E3.13), group G: Biotopes dominated by phanerophytes (G2.215), and group I: Cultivated agricultural biotopes (I2.13, I2.23, I2.241, I2.33, I3.1, I4.111, I4.112, I4.21, I5.5) Species marked small groups in a minor amount of squares (Fig. 23) .

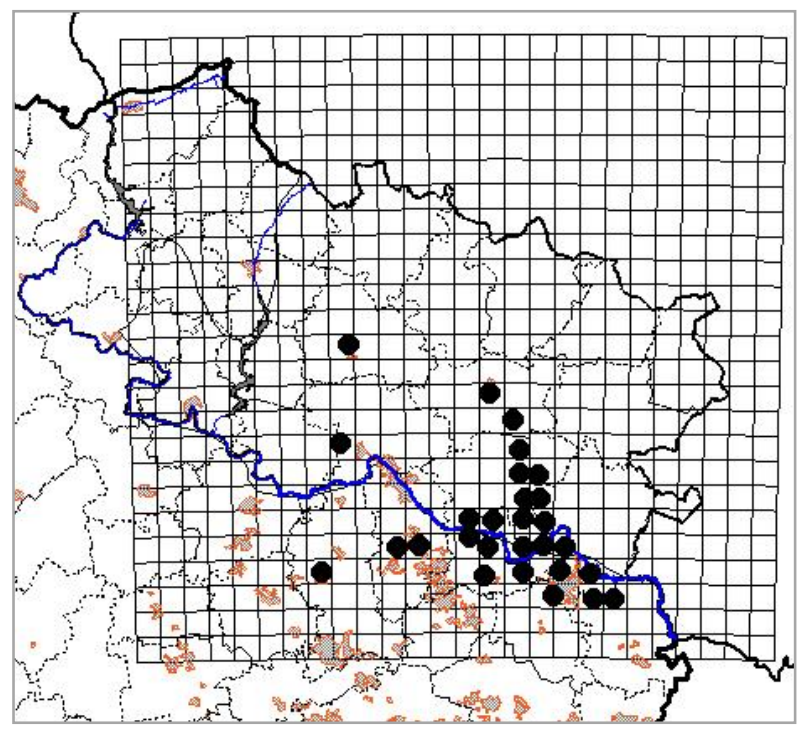

Fig. 21. The map of the distribution of Grindelia squarrosa (Pursh) Dunal in the Starobilsk grass-meadow steppe

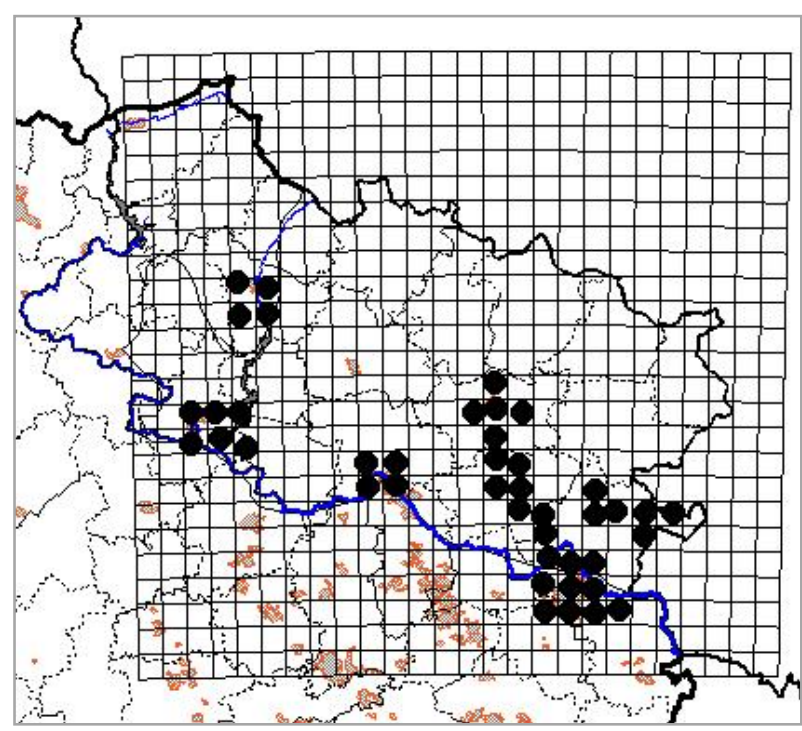

Fig. 23. The map of the distribution of Portulaca oleracea L. in the Starobilsk grass-meadow steppe 
Robinia pseudoacacia - kenophytes of North American origin, ergasiophygophytes, ergasiophytes, phanerophytes, xeromesophytes, scyheliophytes. Species often runs wild from artificial planting along the roads and shelterbelts. As a self-seeding $R$. pseudoacacia occurs in parks and squares. Species found in biotopes group E: Mesophitic and xerophitic grasslands with dominance of hemicryptophytes (E3.13), group G: Biotopes dominated by phanerophytes (G2.215), and group I: Cultivated agricultural biotopes (I2.13, I2.32, I3.2, I4.111, I4.12, I4.21, I4.24). Species marked dispersed in a small number of squares (Fig. 24).

Setaria glauca - archaeophytes of Indo-Malayan origin, epoecophytes, ksenophytes, terophytes, xeromesophytes, heliophytes. Species is pernicious weed, widespread in crops of different cultures.

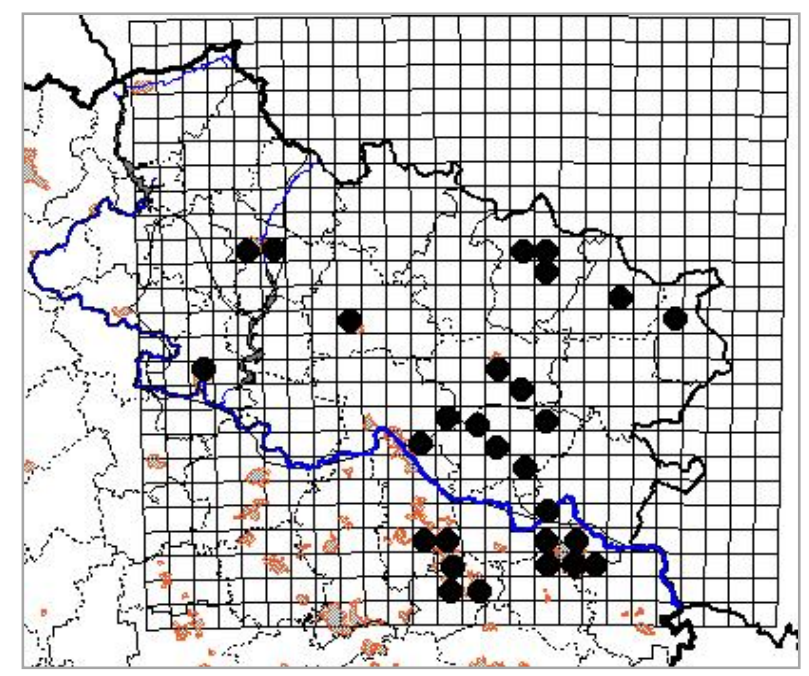

Fig. 24. The map of the distribution of Robinia pseudoacacia L. in the Starobilsk grass-meadow steppe

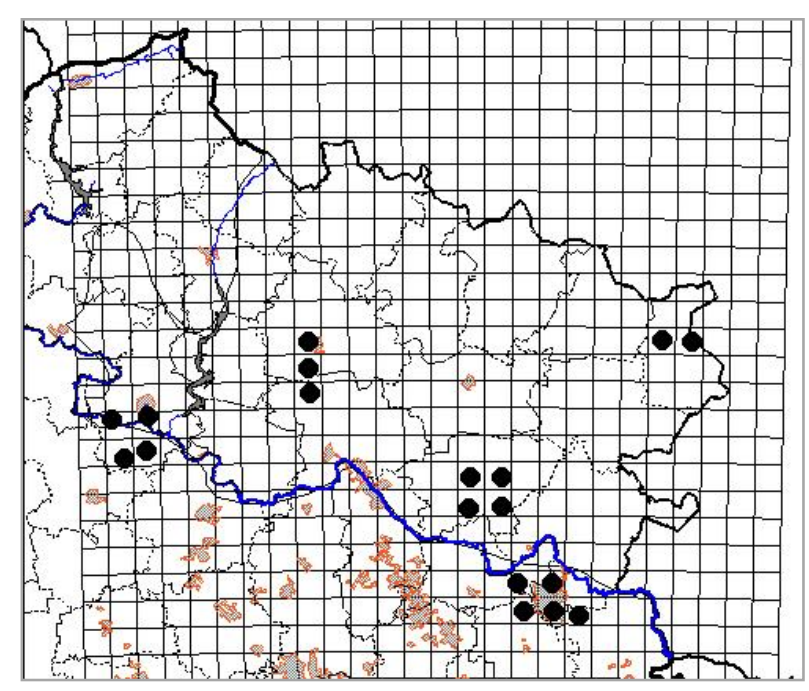

Fig. 26. The map of the distribution of Sonchus oleraceus L. in the Starobilsk grass-meadow steppe
As often, S. glauca occurs along roads, in gardens. In settlements species found on lawns and flower beds as well as other ruderal places. Species found in biotopes group E: Mesophitic and xerophitic grasslands with dominance of hemicryptophytes (E3.13), and group I: Cultivated agricultural biotopes (I1.11, I2.23, I2.242, I2.32, I3.1, I4.112, I4.21). Species marked small groups in a minor amount of squares (Fig. 25).

Sonchus oleraceus - archaeophytes of Mediterraneum origin, epoecophytes, ksenophytes, hemyryptophytes, mesophytes, heliophytes. Species - persistent weeds found in crops almost all crops. Also S.oleraceusgrows on the flower beds and vegetable gardens species found only in group I: Cultivated agricultural biotopes (I1.12, I2.21, I2.23, I2.242, I4.111). Species marked small groups in a minor amount of squares (Fig. 26).

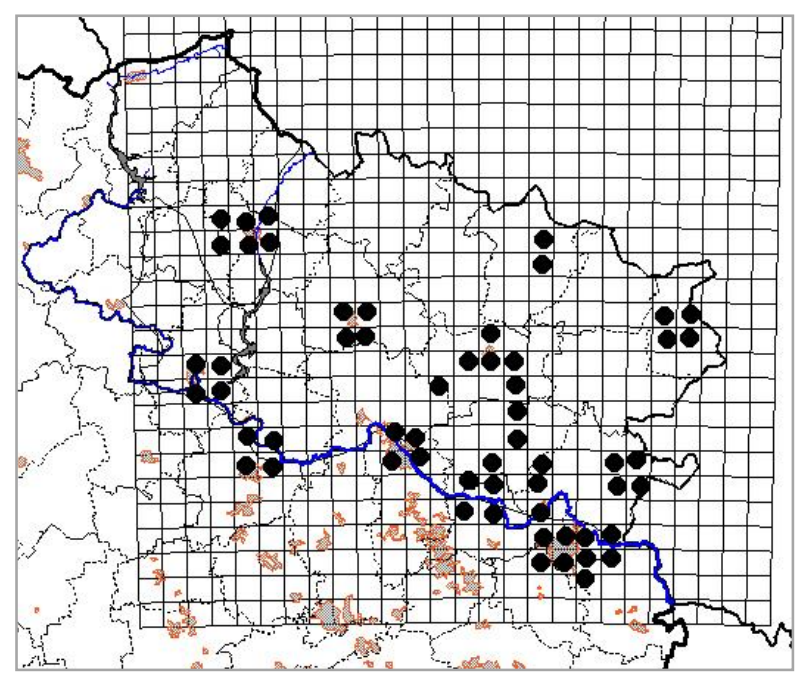

Fig. 25. The map of the distribution of Setaria glauca L. in the Starobilsk grass-meadow steppe

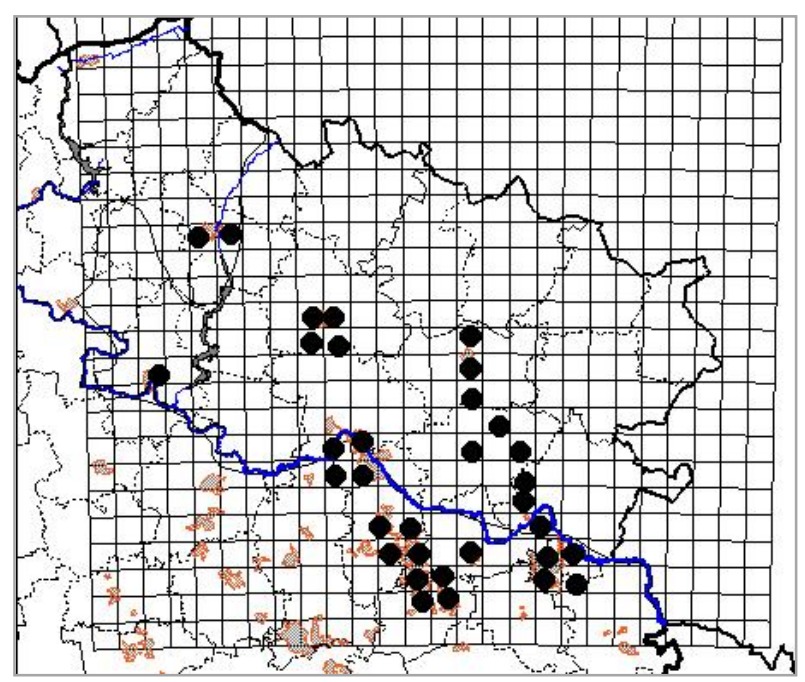

Fig. 27. The map of the distribution of Ulmus pumila L. in the Starobilsk grass-meadow steppe 
Ulmus pumila - kenophytes of Asian origin, epoecophytes, ergasiophytes, phanerophytes, xeromesophytes, heliophytes. The species is widespread in urban areas, has been spreading along the roads at the territory of Starobilsk grass-meadow steppe. Mainly, U. pumila occurs on disturbed soils along the railways and roads. Species found in biotopes group E: Mesophitic and xerophitic grasslands with dominance of hemicryptophytes (E3.13), group G: Biotopes dominated by phanerophytes (G2.215), and group I: Cultivated agricultural biotopes (I2.13, I2.23, I2.33, I3.2, I4.111, I4.112, I4.12, I4.24). Species marked dispersed in a small number of squares (Fig. 27).

Vicia villosa - archaeophytes of Mediterraneum origin, epoecophytes, ksenophytes, terophytes, xeromesophytes, scyheliophytes. Species is found in the steppe areas, the furrows of fields, pastures. Sometimes, V. villosa found on steppe areas. Species found in biotopes group E: Mesophitic and xerophitic grasslands with dominance of

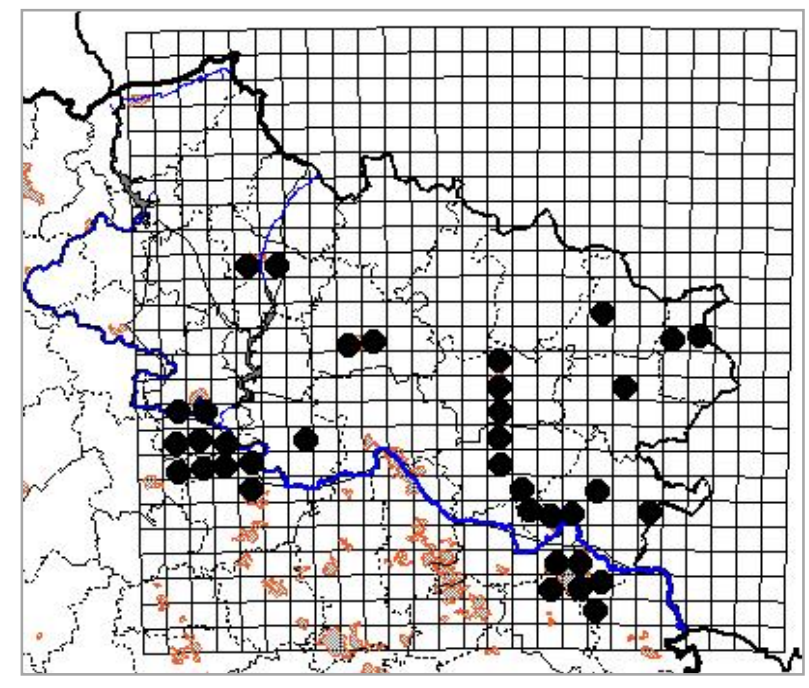

Fig. 28. The map of the distribution of Vicia villosa Roth in the Starobilsk grass-meadow steppe

Most species are found in biotopes group I: cultivated agricultural biotopes 26 species of 28 . Many species found in biotopes group E: Mesophitic and xerophitic grasslands with dominance of hemicryptophytes 20 species and group G: Biotopes dominated by phanerophytes 10 species. Few species found in biotopes group D: Water-logged biotopes (4 species). Only 3 species found in biotopes group F: Biotopes dominated by chamephytes and nanophanerophytes.

\section{Conclusion}

Most of invasive species in the flora Starobilsk grass-meadow steppe are kenophytes, most of hemicryptophytes (E2.123, E3.13), and group I: Cultivated agricultural biotopes (I1.11, I2.21, I2.241, I2.32, I3.1). Species marked dispersed in a small number of squares (Fig. 28).

Xanthium albinum - kenophytes of Middle European origin, epoecophytes, ksenophytes, terophytes, xeromesophytes, heliophytes. Species grows along rivers and often form almost monodominant community. Also $X$. albinum common in ruderal places near housing (landfill, construction site, industrial sites), often, litters crops cultivated plants especially sunflower. Species found in biotopes group D: Water-logged biotopes (D1.221, D1.32, D1.33), group E: Mesophitic and xerophitic grasslands with dominance of hemicryptophytes (E3.13), group G: Biotopes dominated by phanerophytes (G2.215) and group I: Cultivated agricultural biotopes (I1.12, I2.21, I2.22, I2.241, I2.31, I3.1, I4.111, I4.21). Species marked dispersed in a small number of squares (Fig. 29).

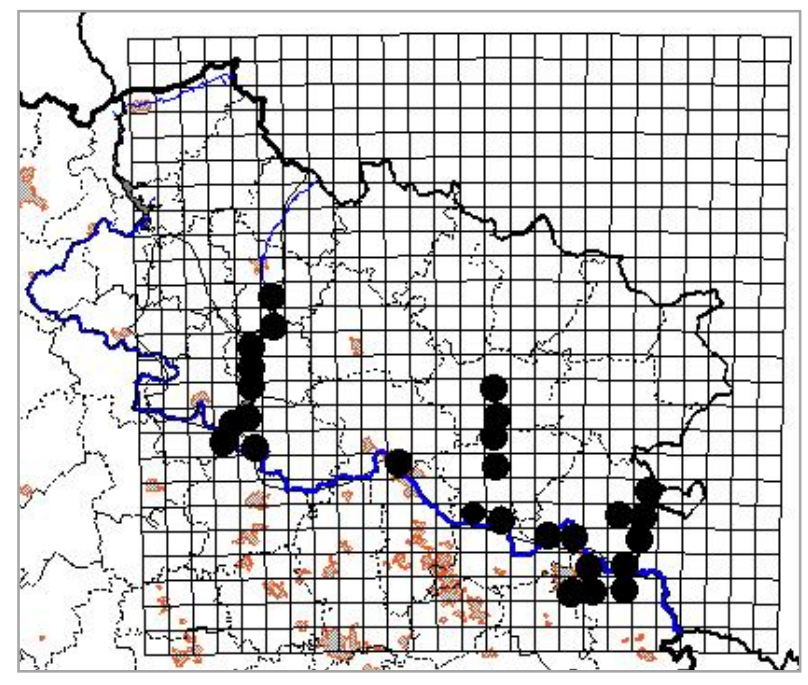

Fig. 29. The map of the distribution of Xanthium albinum (Widder.) H. Scholz. in the Starobilsk grass-meadow steppe

them the North American origin. Half of invasive species are terophytes (14 species), 8 species is hemikryptophytes and 6 are phanerophytes (trees).

By the method of introduction, ksenophytes are dominated; ergaziophytes are only 7 species. Most invasive species in Starobilsk grass-meadow steppe are epekophytes and agriophytes, by degree of naturalization.

For environmental factors we analyzed plants according to the affinity to water and ratio of the light. The vast majority of plants are heliophytes. Only five species are scyo-heliophytes. Most of invasive species are xeromesophytes, and 7 mesophytes and 3 mesoxerophytes. Most plants can withstand dry conditions and light. This enables 
them to take root quickly in disturbed habitats in the steppe zone of Ukraine and even interfere with the semi-vegetable group.

Most invasive species are found in biotopes group I: cultivated agricultural biotopes. Many species found in biotopes group E: Mesophitic and xerophitic grasslands with dominance of hemicryptophytes and group G: Biotopes dominated by phanerophytes. Few species found in biotopes group D: Water-logged biotopes. Only 3 species found in biotopes group F: Biotopes dominated by chamephytesand nanophanerophytes

\section{Acknowledgement}

We would like to thank Dr. Myroslav Shevera (M.G. Kholodny Institute of Botany, NAS of Ukraine) for provided valuable.

\section{References}

Budzhk V.V., Chorney I.I., Tokayuk A.I. 2009. To the method of mapping floras species (on the example of Chernivtsi region). Sci. J. (Biology) Chernivtsy, 445: 168-170.

Burda, R.I. 1991. Anthropogenic transformation of the Flora. Nauk. Dumka, Kyiv.

Didukh Y.P., Fitsailo T.V., Korotchenko I.A., Iakushenko D.M., Pashkevych N.A. 2011. Biotopes of Forest and Forest-Steppe Zones of Ukreine. NAS of Ukraine, Kiev.

Kauffer Ch., Pešek P., Richardson D. 2013. Integrative invasion science: model systems, multi-site studies, focused metaanalysis and invasion syndromes. New Phytologist. Trust, 200: 615-633.

Konoplja O.M. 2002. Flora of Lugansk region. Annotated checklist of vascular plants. V.1. Alma-Mater Press, Lugansk.

Konoplja N.I., Drel V.F. 1998. Alien flora railways of Lugansk region. Alma-Mater Press, Lugansk.

Kucher 0.0. 2011. The history of the study of adventive plants of Starobilsk steppe of south-east of Ukraine. Ind. Botany. Donetsk Botan. Garden of NAS of Ukraine, Donetsk, 11: 141-146.

Kucher 0.0. 2012. Invasive species Grindelia squrrosa (Pursh) Dunal. in the east of Ukraine. [in:] Zagorodniuk I. (ed.) Dynamics of biodiversity 2012. Taras Shevchenko Lugansk Nat. Univ., Luhansk: 96-99.

Kucher 0.O., Guz G.V. 2014. The methodology of Starobilsk grass-meadow steppe flora mapping. The journal of V.N. Karazin. Kharkiv Nat. Univ., series "Biology", 1100(20): 335-338.

Marynych O.M., Parkhomenko G.A., Petrenko A.M, Shischenko P.G. 2003. The improved scheme of physiographic zoning of Ukraine. Ukr. Geogr. J., 1: 16-21.

Mosyakin S.L., Fedoronchuk N.M. 1999. Vascular plants of Ukraine. A nomenclatural checklist. M.G. Kholodny Inst. of Botany, NAS of Ukraine, Kiev.

Ostapko V.M., Boyko A.V., Mosyakin S.L. 2010. Vascular plants of South-Eastern of Ukraine. Noulidzh Press, Donetsk.

Protopopova V.V. 1991. Synantropic flora of Ukraine and its Development. Nauk. Dumka Press, Kiev.

Protopopova V.V., Mosyakin S.L., Shevera M.V. 2002. Plant invasions in Ukraine as a threat to biodiversity: the present situation and tasks for the future. M.G. Kholodny Inst. of Botany, NAS of Ukraine, Kyiv.

Protopopova V.V., Shevera M.V., Mosyakin S.L., Solomacha V.A., Solomacha T.D., Vasileva T.V. Petryk S.P. 2009. The transformer species in the flora of the Northern Black Sea. Ukr. Botan. J., 66(6): 770-782.

Protopopova V.V., Shevera M.V., Mosyakin S.L., Solomakha V.A., Solomakha T.D., Vasilyeva T.V. Petryk S.P. 2009. Invasive plants in the flora of the Northern Black Sea Region (Ukraine). Phytosociocentre, Kyiv.

Protopopova V.V., Shevera M.V., Chorney I.I., Tokaryuk A.V., Budzhak V.V., Korzhan K.V. 2010. The transformers species in the flora of Bucovina Cis-Carpathian area. $U \mathrm{kr}$. Botan. J., 67(6): 852-863.

Protopopova V.V., Shevera M.V., Bagrikova N.A., Riff L.E. 2012. Transformer species in the flora of the South Coast of Crimea. Ukr. Botan. J., 69(1): P 54-68.

Protopopova V.V., Shevera M.V., Mosyakin S.L. 2014. Ergasiophytes of the Ukrainian flora. Biodiv. Res. Conserv., 35: 31-46.

Richardson D.M., Pyśek P., Rejmanek M., Barbour M.G., Panetta F.D., West C.J. 2000. Naturalization and invasion of alien plants: concepts and definitions. Divers. and Distrib., 6: 93-107.

Sova T.V., Borovik L.P., Borozenets V.O. 2000. New species of vascular plants Luhansk Nature Reserve. Ukr. Botan. J., 57(1): 32-36.

Tokhtar V.K. 2005. New finds synanthropic species in the South-Eastern Ukraine. Ind. Botany. Donetsk Botan. Garden of NAS of Ukraine, Donetsk, 5: 61-66.

Vinogradova Y.K., Mayorov S.R., Horun L.V. 2009. Black book of flora of the Middle of Russia. Geos Pess, Moscow. 